( Т. Ю. Киричок, д.т.н., професор, Н. Л. Талімонова, к.т.н., ст. викладач, КП। ім. Ігоря Сікорського, Київ, Україна

\title{
АНАЛІЗ ПРИЧИН ВІДБРАКУВАННЯ БАНКНОТНОЇ ПРОДУКЦІЇ
}

Проаналізовано основні види дефектів банкнотної продукції, які призводять до відбракування, визначено їх відсоткове співвідношення. На основі узагальнення цих даних створено класифікацію основних дефектів банкнотної продукції, що стане підґрунтям для визначення напрямів удосконалення технологічного процесу виготовлення та, як наслідок, підвищення якості банкнотної продукції.

Ключові слова: банкнотне виробництво; контроль якості; дефекти банкнот; брак; відхилення кольору; насиченість відбитку.

\section{Постановка проблеми}

Виготовлення банкнотної продукції вимагає одночасно врахування таких вимог: забезпечення відповідного рівня захисту від фальсифікації, високої якості поліграфічного відтворення та забезпечення зносостійкості. Найбільш складними проблемами виготовлення банкнотної продукції є високі вимоги до точності відтворення дрібних елементів зображення та колірності. Під час розроблення встановлюються мінімальні допуски на відхилення від оригіналу всіх параметрів [1].

Під час контролю на банкнотному виробництві певна частина віддрукованих банкнот не відповідає встановленим критеріям якості. Визначення відсоткового співвідношення основних видів браку банкнотної продукції дасть змогу забезпечити вищий рівень якості під час певних технологічних процесів.

\section{Мета роботи}

Аналіз видів, їх питомої ваги та розроблення класифікації основних дефектів банкнотної продукції, що призводять до її відбракування.

\section{Результати проведених досліджень}

На підставі аналізу джерел [2-8] виявлено, що брак продукції може виникнути з низки причин: через неналежну якість одного або кількох видів друку, несуміщення офсетного та інтагліодруку, перебивання фарби, невідповідне розміщення водяного знака чи захисної стрічки, невідповідність машинозчитуваних характеристик банкноти встановленим вимогам тощо.

Для забезпечення належної якості кінцевого продукту технологічний процес виготовлення банкнот організовано так, що на кожному етапі виробництва контролюється дотримання заданих

\footnotetext{
(c) $2017 \mathrm{p}$.
} 
параметрів якості продукції [1]. Ведення суворої звітності відбувається за рахунок автоматичного розпізнавання та запису всіх серійних номерів банкнот під час контролювання. Придатні банкноти автоматично обандеролюються паперовою стрічкою (по 100 штук) та формуються в пачки по 1000 штук. Банкноти з наявними дефектами піддаються автоматичному знищенню через подрібнення [9]. На рис. 1 показано основні етапи технологічного процесу виготовлення та контролю якості української гривні.

Для проведення дослідження щодо виявлення основних дефектів банкнотної продукції було використано дані, одержані під час інспектування якості сортування банкнот української гривні автоматизованою системою контролю якості банкнот BPS 2000 фірми Giesecke\&Devrient. Ця автоматизована лінія здійснює по- примірниковий контроль зі швидкістю до 40 банкнот за секунду та контролює відповідність виробу таким показникам [9]:

- зображення банкноти у видимому та ІЧ-спектрах випромінювання (лице і зворот);

- взаєморозміщення елементів зображення на виробі;

- лінійні розміри;

- сила сигналу машинозчитуваних ознак: магнетизм, флюоресценція, фосфоресценція.

Для перевірки було відібрано 225000 банкнот з масиву «DN» (масив, що не проходив контролювання після друкування). Швидкість обробки - 100000 банкнот за годину. 3 метою проведення оцінювання якості сортування під час роботи системи кожна сота придатна банкнота масиву направлялася до спеціального укладальника, усі непридатні банкноти - до аудитного укладальника та кишені повернення.
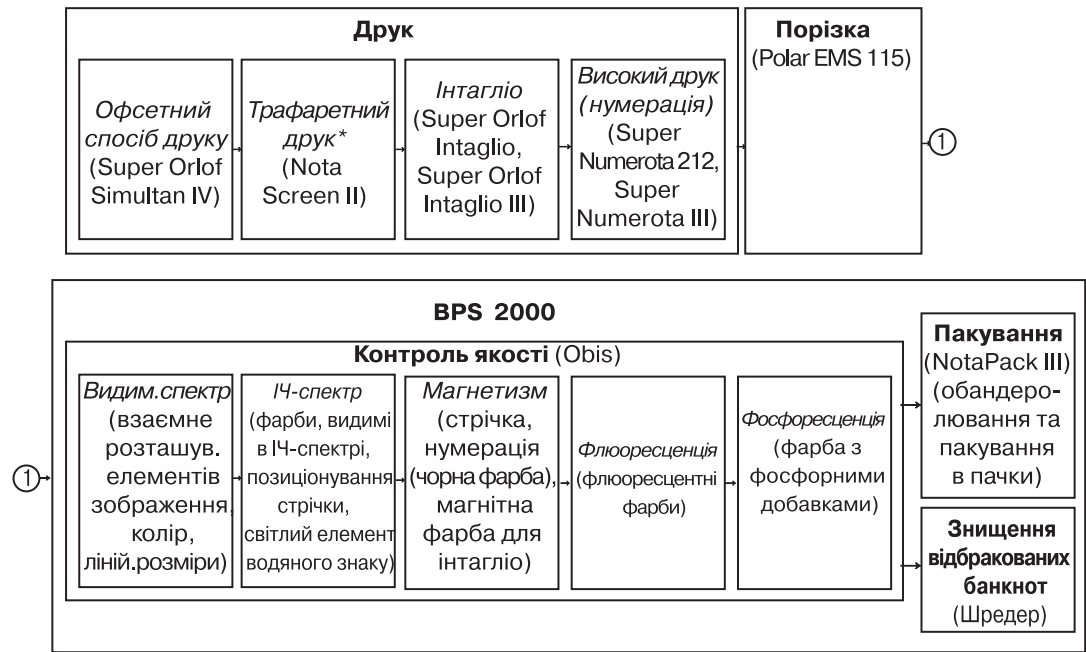

Рис. 1. Процес виготовлення та контролю якості української гривні ( ${ }^{\star}$ застосовується для друку банкнот номіналом 100 грн зразка 2014 року та 500 грн зразка 2015 року) 
Після закінчення робіт було оцінено адаптацію системи до сортування банкнот. На дільниці було проведено додатковий візуальний контроль масиву придатних банкнот зі спеціального укладальника та банкнот, визнаних системою непридатними.

Перевірка якості банкнот вибірки з масиву придатних показала, що всі ці банкноти за показниками якості відповідають вимогам, встановленим ТуУ 22.2-21575489-003:2008 «Банкноти. Технічні вимоги до виконання».

Перевірка непридатних банкнот на відповідність вимогам вищезазначеного ТУ показала, що в цьому масиві наявні відхилення від встановлених показників якості, що представлені на рис. 2.
Найбільша кількість дефектів банкнот пов'язана 3 невідповідною якістю інтагліо (21,1 \%) та офсетного (17,4 \%) видів друку. Для друку банкнот використовують офсетний спосіб друку зі зволоженням та без; офсетним способом друку зображення наносять на лице та на зворот виробу [2, 10]. На рис. 3 подано відсоткове співвідношення видів браку, що виникли під час офсетного способу друку. Найчастіше виникають проблеми з непродруковуванням зображення та недостатньою насиченістю частин відбитка - 23,3 \%, відхиленням кольору відбитка від затвердженого зразка банкноти - 21,4 \%, невідповідністю товщини ліній 17,3 \%, тінінням фарби - 10,7 \%, непродруковуванням на ділянці водяного знака - 9,7\%.
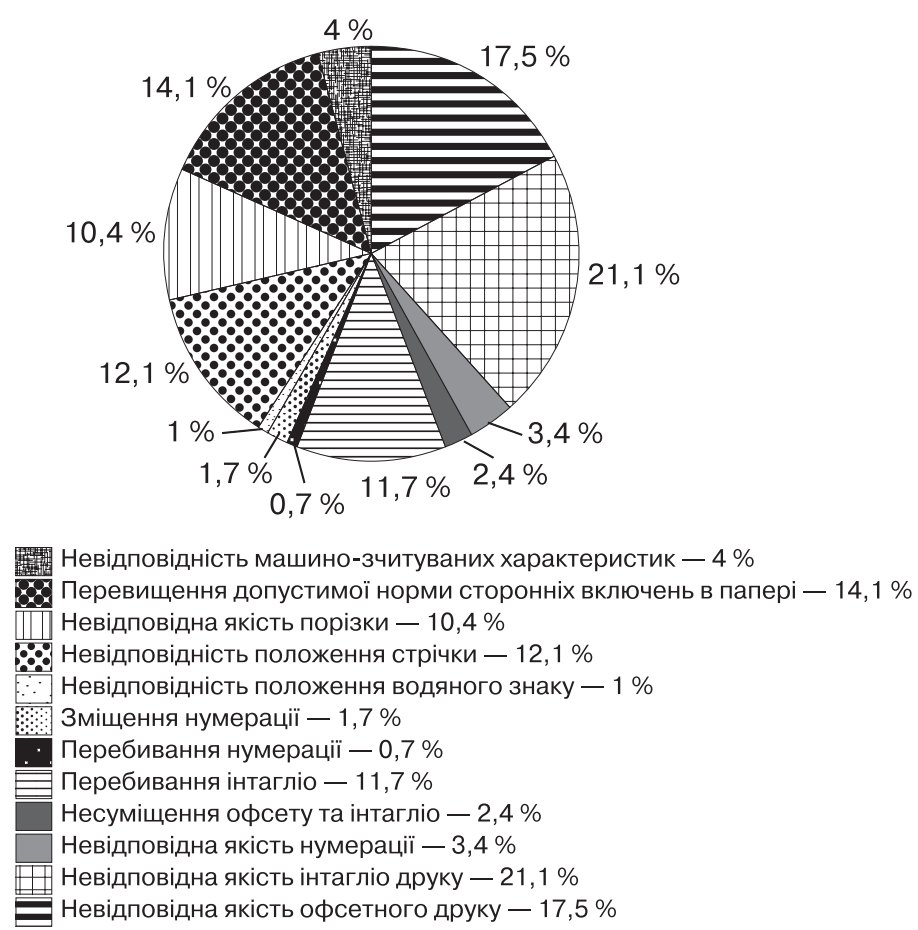

Рис. 2. Види браку готової банкнотної продукції та їх питома вага (для української гривні) 
Причин виникнення подібних дефектів доволі багато - від підбирання матеріалів до забруднення друкарської машини [11]. Непродруковування та недостатня насиченість частин відбитка може бути викликана подаванням недостатньої кількості фарби в фарбову систему та на друкарську форму, або слабким тиском між друкарським і офсетним циліндрами, емульгуванням фарби (для офсетного способу друку зі зволоженням); відхилення кольору відбитка можуть спричинити невідповідності колірних характеристик фарби чи паперу; тініння фарби може бути викликане дефектами друкарської форми, надлишком подаваної фарби або її недостатньою в'язкістю, недостатньою кількістю подаваного зволожувального розчину (для офсетного способу друку зі зволоженням); непродруковування на ділянці водяного знака може бути спричинене неоднорідністю паперу й невідрегульованим подаванням фарби та тиском між друкарським і офсетним циліндрами [11-13].

Узагальнення опрацьованих даних щодо дефектів дало змогу розробити класифікацію основних дефектів банкнотної продукції, наведених на рис. 4. Таке узагальнення дає змогу визначити напрямки вдосконалення технологічного процесу виготовлення банкнотної продукції.

\section{Висновки}

Проаналізовано основні види дефектів банкнотної продукції, які призводять до відбракування,

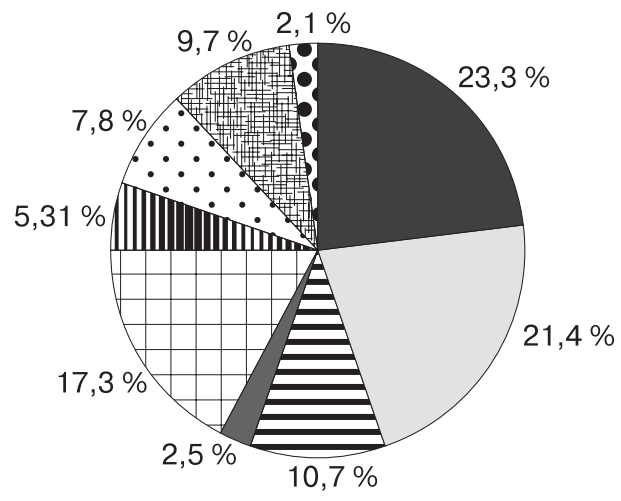

\footnotetext{
П:- Перебивання фарби на зворот $-2,1 \%$

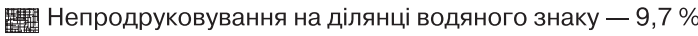

$\because$ Відсутність чіткого розмежування кольорів $-7,8 \%$

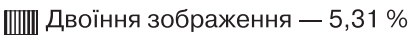

国 Невідповідність товщини ліній - 17,3\%

Фарбові плями - 2,5\%

Е Тініння фарби - 10,7\%

Відхилення кольору відбитка від затвердженого зразка банкноти $-21,4$ \%

Непродруковування зображення $-23,3 \%$
}

Рис. 3. Види браку готової банкнотної продукції, що виникли у процесі офсетного способу друку (для української гривні) 

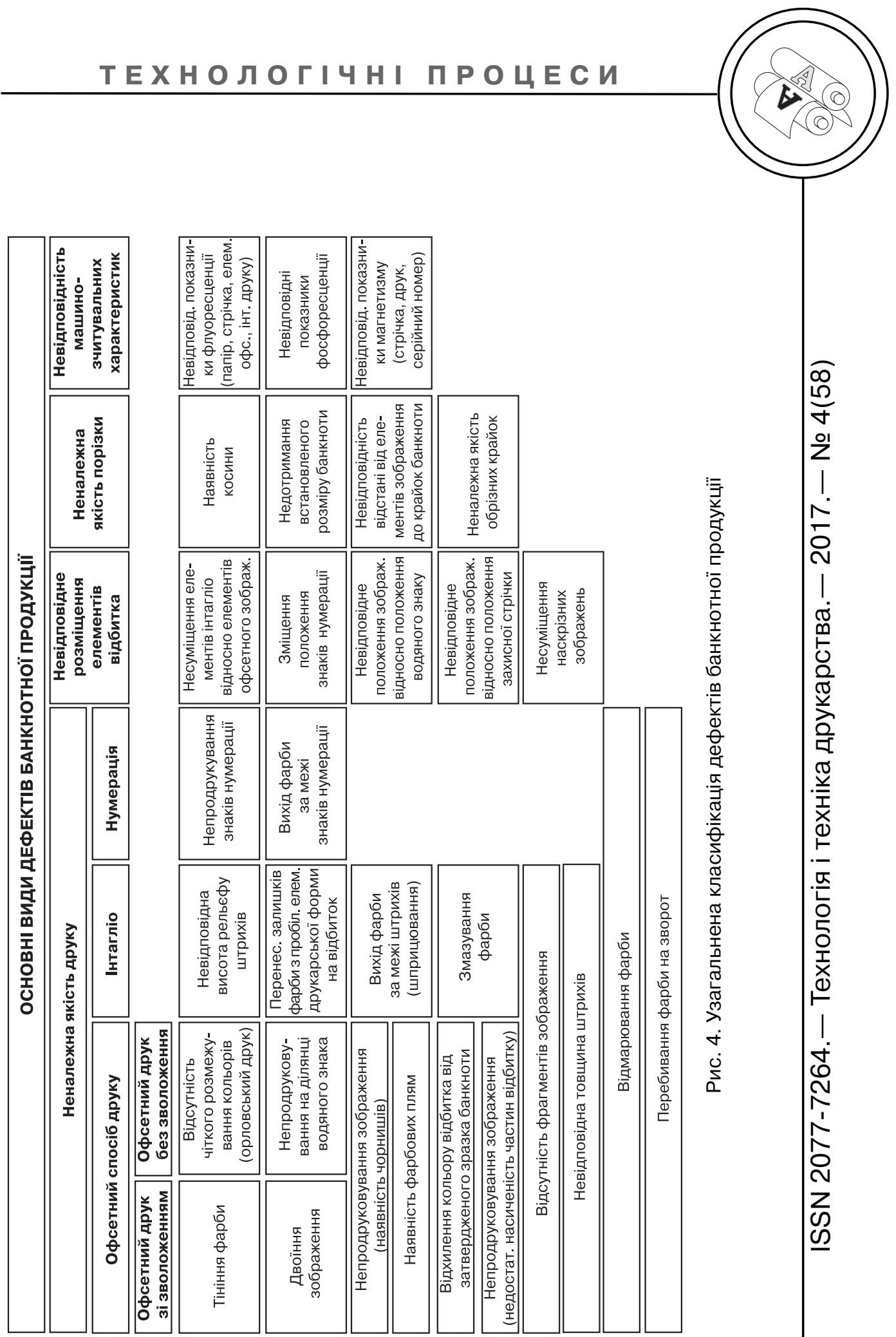
визначено їх відсоткове співвідношення. Найбільший брак спричиняється на етапах офсетного та інтагліодруку $(17,4 \%$ та $21,1 \%$, відповідно). Окремий аналіз видів браку, виявлених після етапу офсетного друку, показав, що найчастішими дефектами $€$ непродруковування зображення та недостатня насиченість частин відбитка - 23,3 \%, відхилення кольору відбитка від затвердженого зразка банкноти $-21,4 \%$, невідповідність товщини ліній 17,3 \%, тініння фарби - 10,7 \%, непродруковування на ділянці водяного знака - 9,7 \%. Створена на основі узагальнення цих даних класифікація основних дефектів банкнотної продукції стане підґрунтям для визначення напрямів удосконалення технологічного процесу виготовлення та, як наслідок, підвищення якості банкнотної продукції.

\section{Список використаної літератури}

1. Киричок Т. Ю. Вирішення багатокритеріальних задач розвитку банкнотного виробництва / Т. Ю. Киричок // Pross. of the 15-th International Conference SAIT 2013. Kyiv, Ukraine. May 27-31, 2013. p. 113.

2. Киричок П. О. Захист цінних паперів та документів суворого обліку / П. О. Киричок, Ю. М. Коростіль, А. В. Шевчук. Київ: НТУУ «КПІ», 2008. 368 с.

3. Кисельова О. Филигранная работа / О. Кисельова // Водяной знак. 2008. № 1-2. С. 39-41.

4. Buitelaar T. Sources of variations in papertint [Electron. resource] / T. Buitelaar. Access link: http://www.currencyaffairs.org/templates/files/library/.

5. De Heij H. A. M. Durable banknote paper [Electron. resource] / H. A. M. de Heij. De Nederlandsche Bank NV., Amsterdam, Netherlands. March, 1995. pp. 1-11. De Nederlandsche Bank NV. Access link: http://www.dnb.nl/binaries.

6. Security features integrated in banknote paper. Billetaria. International Review on Cash Management. April, 2011. Issue 9. pp. 38-39.

7. Темрук В. И. Особенности технологии бумаги для печати документов / В. И. Темрук // Труды Белорусского гос-венного технологич. ун-та. 2008. Сер. 4. «Химия, технология органических веществ и биотехнология». 2008. T. 1. № 4. C. 319-324.

8. Kyrychok T. Badanie szorstkosci powierzchni papierow ze znakami wodnynmi. The Investigation of Roughness for Paper with Watermarks / T. Kyrychok, T. Klymenko, N. Malkush // Przegland papierniczy. 2012. № 7. pp. 414-417.

9. Giesecke \& Devrient: офіційний сайт фірми [Електронний ресурс]. Режим доступу: http://www.gi-de.com.

10. Van Renesse R. L. Optical document security / R. L. van Renesse. Third edition. Boston-London: Artech House, 2005. 368 p.

11. Kappel Ch. Measurement of printing ink penetration in uncoated papers and its influence on print quality / Ch. Kappel, U. Hirn, M. Donoser, W. Bauer // Proceedings of 94th Annual Meeting of Pulp and Paper Technical Association of Canada. Montreal, Canada, February 5-7, 2008. pp. 539-542.

12. Александров Д. Современные средства повышения качества офсетной печати / Д. Александров. СПб.: АО «Текст», 1998. 76 с.

13. Климова Е. Д. Зависимость качества оттисков и стабильность процеса печатания от свойств печатной бумаги / Е. Д. Климова // Вестник: Моск. гос. ун-тет печати. 2005. № 10. С. 63-66. 


\section{References}

1. Kyrychok, T. (2013). Yu. Vyrishennia bahatokryterialnykh zadach rozvytku banknotnoho vyrobnytstva. Journal of Pross. of the 15-th International Conference SAIT 2013, p. 113. Kyiv, Ukraine. May 27-31 [in Ukrainian].

2. Kyrychok, P. O. \& Korostil, Yu. M. \& Shevchuk, A. V. (2008). Zakhyst tsinnykh paperiv ta dokumentiv suvoroho obliku. Kyiv: NTUU 'KPI', 368 p. [in Ukrainian].

3. Kisel'ova, O. (2008). Filigrannaya rabota. Journal of Vodyanoy znak, 1-2, 39-41 [in Russian].

4. Buitelaar, T. Sources of variations in papertint. Retrieved from http://www.currencyaffairs.org/templates/files/library/ [in English].

5. De Heij, H. A. M. (1995). Durable banknote paper. De Nederlandsche Bank NV., Amsterdam, Netherlands, pp. 1-11. De Nederlandsche Bank NV. Retrieved from http://www.dnb.nl/binaries [in English].

6. Security features integrated in banknote paper. (2011). Journal of Billetaria. International Review on Cash Management, 9, pp. 38-39 [in English].

7. Temruk, V. I. (2008). Osobennosti tekhnologii bumagi dlya pechati dokumentov. Journal of Trudy Belorusskogo gos-vennogo tekhnologich. un-ta. Ser. 4. 'Khimiya, tekhnologiya organicheskikh veshchestv i biotekhnologiya', Vol. 1, 4, 319-324 [in Russian].

8. Kyrychok, T. \& Klymenko, T. \& Malkush, N. (2012). Badanie szorstkosci powierzchni papierow ze znakami wodnynmi. Journal of Przegland papierniczy, 7, 414-417 [in Poland].

9. Giesecke\&Devrient. Retrievsd from http://www.gi-de.com [in English].

10. Van Renesse, R. L. (2005). Optical document security. Boston-London: Artech House, 368 p. [in English].

11. Kappel, Ch. \& Hirn, U. \& Donoser, M. \& Bauer, W. (2008). Measurement of printing ink penetration in uncoated papers and its influence on print quality. Journal of Proceedings of 94th Annual Meeting of Pulp and Paper Technical Association of Canada. Montreal, Canada, February 5-7, pp. 539-542 [in English].

12. Aleksandrov, D. (1998). Sovremennye sredstva povysheniya kachestva ofsetnoy pechati. SPb.: AO 'Tekst', 76 p. [in Russian].

13. Klimova, E. D. (2005). Zavisimost' kachestva ottiskov i stabil'nost' protsesa pechataniya ot svoystv pechatnoy bumagi. Journal of Vestnik: Mosk. gos. un-tet pechati, 10, 63-66 [in Russian].

Проанализированы основные виды дефектов банкнотной продукции, которые приводят к отбракованию, определено

их процентное соотношение. На основе обобщения этих данных была создана классификация основных дефектов

банкнотной продукции, что станет основой для определения направлений совершенствования технологического процесса изготовления и, как следствие, повышения качества банкнотной продукции.

Ключевые слова: банкнотное производство; контроль качества; дефекты банкнот; брак; отклонения цвета; насыщенность оттиска. 
The main types of defects in banknote products that led to their rejection were analyzed. The percentage of these defects was determined. On the basis of the generalization of these data, a classification of major defects in banknote products was created. This will be the basis for identifying areas for improving the manufacturing process and, consequently, improving the quality of banknote products.

Keywords: banknote production; quality control; banknote defects; reject; color differences; saturation of a print. 